\section{Australian Journal of \\ Crop Science}

AJCS 13(06):934-943 (2019)

doi: 10.21475/ajcs.19.13.06.p1682
AJCS

ISSN:1835-2707

\title{
Evaluation of vitamin C, nitrate and chlorophyll content determined in lettuce (Thaís, Vanda, Verônica) cultivated in hydroponic system using wastewater
}

\author{
Josilda de França Xavier ${ }^{1 *}$, Carlos Alberto Vieira de Azevedo ${ }^{1,2}$, Márcia Rejane de Queiroz Almeida \\ Azevedo $^{3}$, Jacqueline da Silva Mendes ${ }^{1}$, Josely Dantas Fernandes ${ }^{3}$, Antonio Fernandes Monteiro \\ Filho $^{3}$
}

\author{
${ }^{1}$ Federal University of Campina Grande, Academic Unit of Agricultural Engineering, Campina Grande, 58.429- \\ 140, Paraíba, Brazil \\ ${ }^{2}$ Fellow of CNPq Reseach Productivity, level 1B, Brazil \\ ${ }^{3}$ State University of Paraíba, Center of Environmental and Agrarian Sciences, Lagoa Seca, 58.117-000, Paraíba, \\ Brazil
}

\section{*Corresponding author: josildaxavier@yahoo.com.br}

\begin{abstract}
The objective of this work was to determine the levels of vitamin C, nitrate and chlorophyll in three lettuce cultivars in a hydroponic system using waste- and well-water. The experiment was conducted in a hydroponic system using laminar flow technique and nutrients in a protected environment. The experimental design was randomized blocks with treatments set up in split-plots with three replications, whose main plots devoted to lettuce cultivars and sub-plots to hydroponic solutions. The experimental solutions consisted of 7 nutrients $(S)$ : $S_{1}=$ Furlani solution, $S_{2}=$ domestic wastewater, $S_{3}=$ optimized domestic wastewater, $S_{4}=$ well water $S_{5}=$ optimized well water; $S_{6}=$ reactor wastewater solution and $S_{7}=$ optimized reactor wastewater solution and the subplot for the three cultivars of iceberg lettuce (Verônica, Vanda, and Thais). The following variables were determined: nitrate, vitamin $\mathrm{C}$ and chlorophyll content using the method described by Lichtenthaler. The results indicated that highest content of vitamin $C$ was found in the Vanda cultivar using the $S_{1}$ solution. For Veronica cultivar, the highest levels of vitamin $C$ were observed at solutions $S_{1}, S_{2}, S_{3}, S_{4}$, and $S_{7}$. The solutions $S_{2}$ and $S_{3}$ did not differ from one another in all three cultivars. For the Vanda cultivar, solutions $S_{1}, S_{4}$ and $S_{7}$ were the ones that promoted the highest levels of nitrate, 4.61; 3,32 and $2.64 \mathrm{~g} \mathrm{~kg}^{-1}$, respectively. Evaluating the effect of the solution within the cultivars, we verified that the highest nitrate values obtained from $S_{2}$ nutrition for cultivars Thais and Verônica. Regarding the $S_{5}$ solution, the Verônica cultivar presented the highest concentration of this nutrient. The cultivate Thaís, the highest contents of chlorophyll $b$ were found in solutions $S_{7}$, $\mathrm{S}_{6}, \mathrm{~S}_{4}, \mathrm{~S}_{3}$ and $\mathrm{S}_{2}$, where they did not differ significantly. Regarding to Vanda cultivar the highest values of chlorophyll $b$ were present in solutions $S_{2}$ and $S_{5}$. The Verônica cultivar independent of the solution used presented the same values of this pigment.
\end{abstract}

Keywords: ascorbic acid; physiology; hydroponics; Lactuca sativa; reuse.

Introduction

Lettuce (Lactuca sativa L.) is the most widespread leafy vegetable currently cultivated in almost all countries. Its cultivation is done intensively and is generally practiced by family agriculture, responsible for the generation of five direct jobs per hectare (Alencar et al., 2012). Lettuce has vitamins, minerals and vitamins $A, B, C$ calcium and iron. Due to its low-calorie content and easy digestion, it is recommended for diets (Sala and Costa, 2012). According to Sala and Costa (2012), a hydroponic lettuce crop is able to extract approximately $77 \%$ of the phosphorus and $80 \%$ of the nitrogen contained in the sewage treatment effluent solution, showing that besides its capability to extract, the nutrients are also available in effluents.

Some studies developed with NFT technique ("Nutrient Film Technique"), hydroponic system or in culture with an inert substrate using wastewater mainly for lettuce cultivation (Santos et al., 2012).

Cova et al. (2017) studied lettuce cultivation in a hydroponic system and observed that the choice of the hydroponic system and the recirculation interval for lettuce acculturation depends on the quality of the water in preparation of the nutrient solution. Vitamin C (ascorbic acid) is an indispensable nutrient for the human body. Several animals, can produce it endogenously from other nutrients (Teixeira Neto, 2009). They also verified that the salinity of the water used in the preparation of the nutrient solution resulted in a decrease in growth and in the contents of $\mathrm{K}+$ and $\mathrm{NO}_{3}$ - and increased $\mathrm{Na}$ + and $\mathrm{Cl}$ - contents in the plants. Vitamin $\mathrm{C}$ has an antioxidant action where these chemical compounds can prevent or reduce the oxidative damage of lipids, proteins and nucleic 
acids caused by reactive oxygen species, which include free radicals. The antioxidants have the ability to react with radicals free and thus restrict the harmful effects to the organism (Couto and Canniatti-Brazaca, 2010).

Lettuce has a great ability to accumulate nitrate $\left(\mathrm{N}^{-} \mathrm{NO}_{3}-\mathrm{)}\right.$ in its leaves, and when this mineral is absorbed in excess it results in a decreased quality of leaves. It is necessary to mention that when nitrate is consumed in high amounts, it can cause serious damages to human health, such as the formation of nitrosamines, a potentially carcinogenic substance (Faquin and Andrade, 2004). The nitrate is usually present in plants. It may have nitrate origin added as fertilizer or formed in the substrate by mineralization or nitrification (Maynard et al., 1976). The permitted nitrate limits are not well-defined and differ widely from one author to another. The World Food and Agriculture Organization (FAO) and the World Health Organization (WHO) have established an acceptable daily dose of $3.65 \mathrm{mg}$ of the $\mathrm{NO}_{3}$ - ion and 0.133 $\mathrm{mg}$ of the $\mathrm{NO}_{2}-\mathrm{kg}^{-1}$ bodyweight ion.

Photosynthesis is the process by which plants turn solar energy into chemical energy. Photosynthetic organisms use solar energy to synthesize carbohydrates from carbon dioxide and water, with the release of oxygen. The energy stored in these molecules can be used later to boost cellular processes in the plant and serve as a source of energy for all life forms (Taiz and Zeiger, 2006). Photosynthesis involves reactions with absorption of radiant energy (light) directed to a reaction center, where a series of reactions is initiated, which can be divided into two phases: (1) photochemical phase for the capture of light energy and its transformation into energy chemistry Adenosine triphosphate (ATP), Nicotinamide Adenine Dinucleotide Phosphate (NADPH) for the reduction of atmospheric $\mathrm{CO}_{2}$ to carbohydrate, but also for other reactions that consume Adenosine triphosphate Adenosine triphosphate and Nicotinamide Adenine Dinucleotide Phosphate and (2) Calvin cycle, that is the enzymatic reactions of incorporation of $\mathrm{CO}_{2}$ (TIM and Zeiger, 2006). In order to evaluate the effect of NADPH on the reaction time (Pimentel, 1998; Taiz and Zeiger, 2006). The chlorophyll and carotenoid contents in the leaves are used to estimate the photosynthetic potential of the plants, within their direct connection with the absorption and transfer of light energy besides growth and adaptation to different environments (Rego and Possamai, 2006).

In this perspective, the objective of this work was to determine the levels of vitamin $C$ and nitrate in the three lettuce cultivars in a hydroponic system using wastewater and well-water conditions.

\section{Results and discussion}

\section{Levels of vitamin C (VCC) depends on solution (S) nitrogen} content and cultivar (C)

It is observed in Table 1 that the vitamin C (VCC) and nitrate levels in the first experiment were significantly influenced by the interaction between the solution (S) and cultivar (C) factors at the $p<0.01$ level. The same behavior was not observed for the nitrate content in the second experiment, being influenced by the isolated effect of the factors $(S)$ and
(C), both at the level of $p \leq 0.01$. The same behavior was not observed for the nitrate content in the second experiment, being influenced by the isolated effect of the factors (S) and (C), both at the level of $p \leq 0.01$.

Comparing the solutions, it is observed in Fig. 1 that the cultivar Thaís presented lower vitamin C content (VCC) with the Furlani solution $\left(\mathrm{S}_{1}\right)$, whose untransformed means corresponds to $\left(45.78 \mathrm{mg} \cdot 100 \mathrm{~g}^{-1}\right)$. In Vanda cultivar, the highest vitamin C content (VCC) was verified in $\mathrm{S}_{1}$ solution whose untransformed mean corresponds to $(57.33 \mathrm{mg} .100 \mathrm{~g}$ $\left.{ }^{1}\right)$. For the cultivar, Verônica, except for the solutions: household wastewater $\left(S_{2}\right)$, optimized well water $\left(S_{5}\right)$ and wastewater from the UASB reactor $\left(S_{6}\right)$, the vitamin $C$ contents (VCC) did not differ with other solutions.

Fig. 1 shows that the levels of vitamin C (VCC) of the three cultivars do not statistically differ with the solutions of raw sewage $\left(S_{2}\right)$ and optimized crude sewage $\left(S_{3}\right)$. It is also observed in Fig. 1 that the cultivars Thais and Veronica presented similar levels of vitamin C (TVC) with the use of solutions: well water $\left(\mathrm{S}_{4}\right)$ and wastewater of the UASB optimized reactor $\left(\mathrm{S}_{7}\right)$ (Fig. 1). We verified that vitamin $C$ contents (VCC) were higher than those reported by Ohse et al. (2001), where they found vitamin $C$ levels ranged from $41.89 \mathrm{mg} \cdot 100 \mathrm{~g}^{-1}$ to $19.24 \mathrm{mg} \cdot 100 \mathrm{~g}^{-1}$, whereas Martins and Riella (1993), found 18.0; 7.6 and $9.5 \mathrm{mg} 100 \mathrm{~g}^{-1}$, respectively. Oliveira et al. (2009), evaluated vitamin C content in five lettuce cultivars and irrigated them with five levels of salinity in a substrate composed of soil and cattle manure and verified that the vitamin $\mathrm{C}$ content of lettuce leaves ranged from $20.4 \mathrm{mg} 100 \mathrm{~g}^{-1}$ to $46.5 \mathrm{mg} 100 \mathrm{~g}^{-1}$ among the cultivars studied. The highest variation of vitamin $C$ content in different saline levels was found in Grande Lagos cultivar 659 $(41.4 \%)$ and the lowest variation in Stella cultivar (17.5\%).

It is observed in Fig. 2 that the nitrate contents $\left(\mathrm{NO}_{3}-\mathrm{kg}^{-1}\right)$ of the cultivars Thaís, Vanda and Verônica do not differ among themselves using solutions $S_{1}, S_{3}, S_{4}$, and $S_{7}$.

When the interaction of solution and cultivars was analyzed, the highest nitrate value of $4.67 \mathrm{~g} \mathrm{~kg}^{-1}$ in the fresh mass was observed for Thais using solution $\mathrm{S}_{1}$. For Veronica the highest means of 4.93 and $3.65 \mathrm{~g} \mathrm{~kg}^{-1}$ in the fresh mass were observed in solutions $S_{5}$ and $S_{1}$, respectively. As for the Vanda cultivar, solutions $S_{1}, S_{4}$ and $S_{7}$ were the ones that promoted the highest levels of nitrate, $4.61 ; 3.32$ and $2.64 \mathrm{~g} \mathrm{~kg}^{-1}$ respectively. For example, Silva et al. (2011) found $41.3 \%$ lower values of nitrate concentration in lettuce plants produced in the organic system compared to conventional system, and 3.7 to 4.8 times lower in the hydroponic system. Sarmento et al. (2014) found that vitamin C content of lettuce was increased in response to increased salinity of nutrient

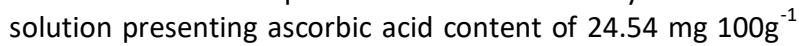
when irrigated with nutrient solution with EC of $1.1 \mathrm{dS} \mathrm{m}^{-1}$ and maximum value of $26.67 \mathrm{mg} 100 \mathrm{~g}^{-1}$ in nutrient solution with EC of $5.7 \mathrm{dS} \mathrm{m}^{-1}$.

The permitted nitrate levels (limits) are not well defined and are very divergent among several authors and countries, but the World Food Organization (WFO) and the World Health Organization (WHO) have established an acceptable the daily dose of $3.65 \mathrm{mg}$ of the $\mathrm{NO}_{3}$ - ion and $0.133 \mathrm{mg}$ of the $\mathrm{NO}_{3}-\mathrm{kg}^{-1}$ bodyweight ion. They also recommend that the $\mathrm{NO}_{3}$ - content in drinking water should be less than $50 \mathrm{mg}$. L. 
Table 1. Analysis of variance of vitamin C contents (VCC) and of the nitrate $\left(\mathrm{NO}_{3}{ }^{-}\right)$in the fresh mass (FM) of the three lettuce cultivars submitted to the different treatments at the end of the hydroponic cultivation.

\begin{tabular}{lllcc}
\hline & & \multicolumn{3}{c}{ Average Square (AS) } \\
\cline { 3 - 5 } Source of Variation & $\mathrm{DF}$ & $\mathrm{VCC}^{(1)} \mathrm{mg}^{-100 \mathrm{~g}^{-1}}$ & $\mathrm{NO}_{3}{ }^{*} \mathrm{~kg}^{-1}$ on $\mathrm{MF}^{(2)} 1^{0}$ experiment & $\mathrm{NO}_{3}{ }^{*} \mathrm{~kg}^{-1}$ on FM $^{(2)} 2^{0}$ experiment \\
\hline Solution (S) & 6 & $271.778 .14^{\mathrm{ns}}$ & $17.19^{* *}$ & $11.11^{* *}$ \\
Block & 2 & $1.332 .441 .99^{\mathrm{ns}}$ & $1.05^{\mathrm{ns}}$ & $0.54^{\mathrm{ns}}$ \\
Residue of the parcel & 12 & 425.881 .66 & 1.64 & 0.20 \\
Cultivar (C) & 2 & $1.698 .492 .76^{*}$ & $3.52^{*}$ & $4.96^{* *}$ \\
Cultivar x Solution & 12 & $5.382 .824 .10^{* *}$ & $5.56^{* *}$ & $1.49^{\text {ns }}$ \\
Residue of the subparcel & 26 & 497.970 .96 & 0.99 & 0.80 \\
CV 1 & & 7.78 & 69.85 & 38.30 \\
CV 2 & 8.42 & 54.31 & 76.80 \\
General Average & 8.383 .83 & 1.83 & 1.16 \\
\hline
\end{tabular}

DF - degree of free ${ }^{(1)}$

$\frac{x^{2,5}-1}{2,5}$

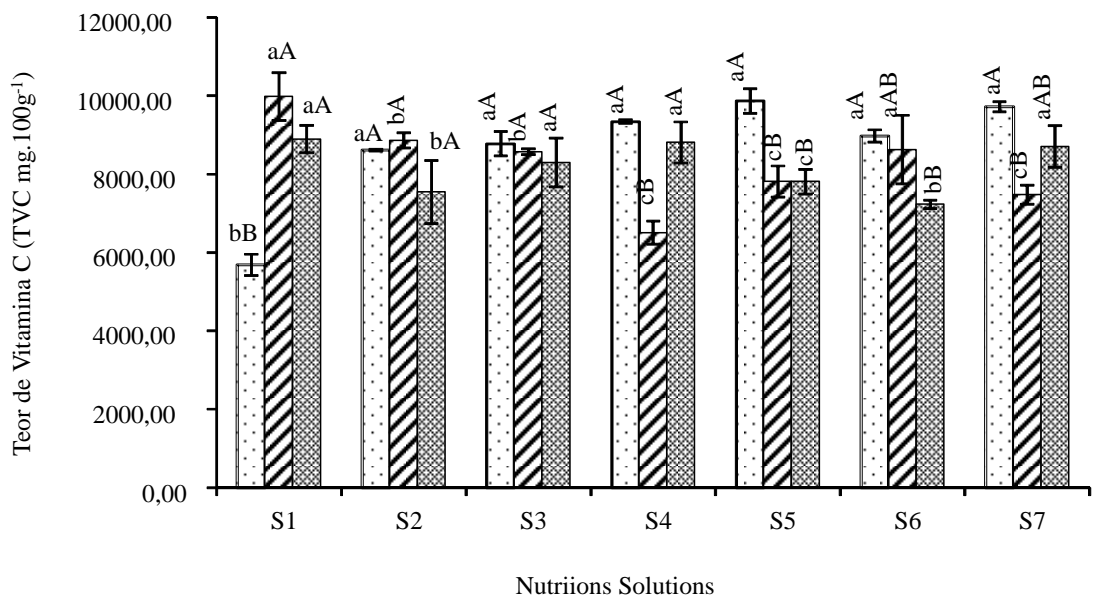

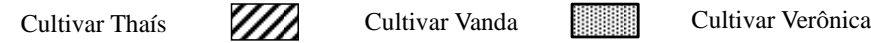

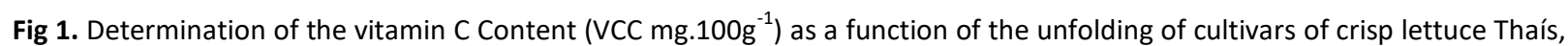
Vanda and Verônica and solutions at the end of the third experiment. Means followed by the same lowercase letter, the solutions do not differ among themselves within the same cultivar and averages followed by the same capital letter, the cultivars do not differ among themselves within the same solution. $S_{1}=$ Furlani solution; $S_{2}=$ domestic wastewater; $S_{3}=$ optimized domestic wastewater, $S_{4}=$ well water $S_{5}=$ optimized well water; $S_{6}=$ reactor wastewater solution and $S_{7}=$ optimized reactor waste-water solution.

Table 2. Analysis of variance of the chlorophyll content ( $\mathrm{Chl} \mathrm{a)}$, ( $\mathrm{Chl} \mathrm{b),} \mathrm{(Chl} \mathrm{total)} \mathrm{and} \mathrm{Carotenoids} \mathrm{at} \mathrm{the} \mathrm{third} \mathrm{end} \mathrm{of} \mathrm{the}$ hydroponic cultivation of the three cultivars of the lettuce submitted to the different treatments.

\begin{tabular}{llccc}
\hline & & Middle square & (MS) & \\
\cline { 3 - 5 } Source of Variation & GF & Chl $b$ & Chl fully & Carotenoids \\
\hline Solution (S) & 6 & $17.27^{\text {ns }}$ & $178.527 .90^{\text {ns }}$ & $3.10^{\text {ns }}$ \\
Block & 2 & 22.07 & 111.311 .44 & 1.37 \\
Residue portion & 12 & $10.74^{\text {ns }}$ & $115.237 .47^{\text {ns }}$ & $1.24^{\text {ns }}$ \\
Cultivar (C) & 2 & $205.34^{* *}$ & $1.611 .112 .38^{* *}$ & $18.25^{* *}$ \\
Cultivar x Solution & 12 & $46.22^{* *}$ & $318.148 .17^{* *}$ & $3.02^{* *}$ \\
Residue of the subplot & 26 & 11.84 & 102.027 .36 & 1.38 \\
CV 1 & & 24.22 & 31.17 & 37.85 \\
CV 2 & & 25.44 & 29.33 & 39.97 \\
Overall erage & & 13.53 & 1.089 .12 & 2.94
\end{tabular}

Overall erage

1.089 .12

2.94

GF - degree of freedom; ns not significant; ${ }^{* *}$ significant at $1 \%$ probability level $(p<0.01)$; ${ }^{*}$ significant at the $5 \%$ probability level $(0.01 \leq p<0.05)$ by the $\mathrm{F}$ test; $\mathrm{CV}$ $=\quad x^{2,348}-1$ coefficient of variance; (1)

$$
\frac{x^{2,348}-1}{2,348}
$$




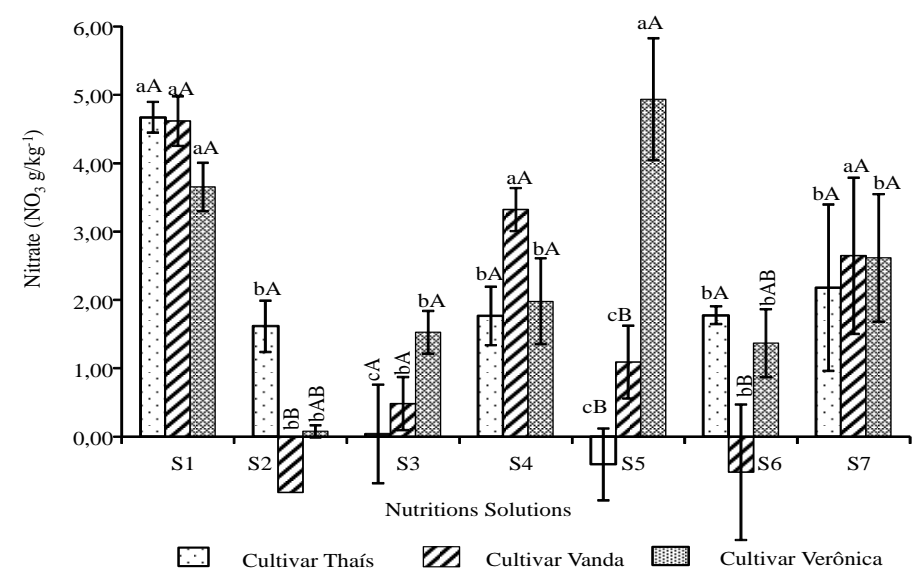

Fig 2. Determination of the nitrate content $\left(\mathrm{NO}_{3}-\mathrm{g} \cdot \mathrm{kg}^{-1}\right.$ in the fresh mass) as a function of the unfolding of lettuce cultivars of Thaís, Vanda and Verônica and solutions at the end of the first experiment. Means followed by the same lowercase letter, the solutions do not differ among themselves within the same cultivar and averages followed by the same capital letter, the cultivars do not differ among themselves within the same solution (First experiment). $S_{1}=$ Furlani solution; $S_{2}=$ domestic wastewater; $S_{3}=$ optimized domestic wastewater, $S_{4}=$ well water $S_{5}=$ optimized well water; $S_{6}=$ reactor waste-water solution and $\mathrm{S}_{7}=$ optimized reactor waste water solution.

Table 3. Physical-chemical characterization of waters used in hydroponic irrigation.

\begin{tabular}{llll}
\hline Determinations & Domestic wastewater $\left(\mathrm{S}_{2}\right)$ & Well water $\left(\mathrm{S}_{4}\right)$ & $\begin{array}{l}\text { Wastewater from the (UASB) } \\
\text { reactor }\left(\mathrm{S}_{6}\right)\end{array}$ \\
\hline $\mathrm{pH}$ & 7.7 & 7.4 & 7.2 \\
Electric conductivity $\left(\mathrm{dSm}^{-1}\right)$ & 0.957 & 2133 & 2.502 \\
Calcium $\left(\mathrm{mmol}_{\mathrm{c}} / \mathrm{L}\right)$ & 3.62 & 3.98 & 5.98 \\
Magnesium $\left(\mathrm{mmol}_{\mathrm{c}} / \mathrm{L}\right)$ & 0.75 & 3.47 & 3.42 \\
Sodium $\left(\mathrm{mmo}_{\mathrm{c}} / \mathrm{L}\right)$ & 3.94 & 10.57 & 15.55 \\
Potassium $\left(\mathrm{mmol}_{\mathrm{c}} / \mathrm{L}\right)$ & 0.38 & 1.26 & 0.01 \\
Chlorides $\left(\mathrm{mmol}_{\mathrm{c}} / \mathrm{L}\right)$ & 6.42 & 9.99 & 23.23 \\
Carbonates $\left(\mathrm{mmol}_{\mathrm{c}} / \mathrm{L}\right)$ & 0.00 & 0.00 & 0.00 \\
Bicarbonate $\left(\mathrm{mmol}_{\mathrm{c}} / \mathrm{L}\right)$ & 1.31 & 10.95 & 3.25 \\
phosphorus $\left(\mathrm{mg} \mathrm{L}^{-1}\right)$ & 4.51 & 29.30 & 4.14 \\
Nitrate $\left(\mathrm{NO}_{3}^{-}\right)\left(\mathrm{mg} \mathrm{L}^{-1}\right)$ & 16.73 & 0.00 & 1.03 \\
Ammonia $\left(\mathrm{NH}_{3}\right)\left(\mathrm{mg} \mathrm{L}^{-1}\right)$ & 0.61 & 1.27 & 58.6 \\
Sodium adsorption ratio $(\mathrm{SAR})$ & 2.57 & 6.93 & 8.53 \\
Class of water for irrigation & $\mathrm{C}_{2} \mathrm{~S}_{1} \mathrm{~T}_{2}$ & $\mathrm{C}_{3} \mathrm{~S}_{1} \mathrm{~T}_{3}$ & $\mathrm{C}_{3} \mathrm{~S}_{1} \mathrm{~T}_{3}$ \\
\hline
\end{tabular}

$\mathrm{S}_{2}=$ domestic wastewater; $\mathrm{S}_{4}=$ well water and $\mathrm{S}_{6}=$ reactor waste water solution and. Class of water for irrigation: Salinity (C), sodicity (S) and toxicity (T) in ions. $\mathrm{C}_{2}-$ Medium salinity water Água de média salinidade, $\mathrm{C}_{3}$ - High salinity water Água de alta salinidade. $\mathrm{S}_{1}$ - water low sodium or low sodium concentration. $\mathrm{S}_{2}$ - medium sodic water or medium sodium concentration. $\mathrm{T}_{2}$ moderate toxicity problema and $\mathrm{T}_{3}$ - severe toxicity problema.

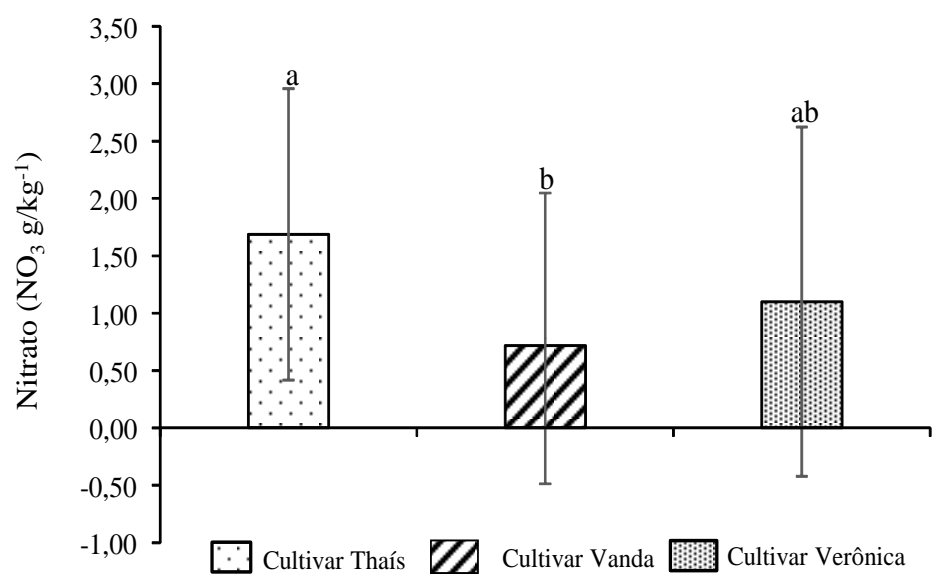

Fig 3. Determination of nitrate content $\left(\mathrm{NO}_{3}-\mathrm{kg} \mathrm{kg}^{-1}\right)$ as a function of the isolated effect of the cultivars of crisp lettuce Thaís, Vanda and Verônica at the end of the second experiment. Averages followed by the same lowercase letter cultivars do not differ. 
Table 4 - Chemical composition of mineral nutritive solutions.

\begin{tabular}{ll}
\hline Solution & \\
\hline Mineral salts & Furlani \\
\hline $\mathrm{g} 1000 \mathrm{~L}^{-1}$ of water & \\
\hline $\mathrm{NO}_{3}$ - Nitrate & 200.44 \\
$\mathrm{NH}_{4}$ - Ammonium & 16.51432 \\
$\mathrm{P}$ - Phosphor & 32.7 \\
$\mathrm{~K}$ - Potassium & 310.275 \\
$\mathrm{Ca}$ - Calcium & 168 \\
$\mathrm{Mg}$ - Magnesium & 24.65 \\
$\mathrm{~S}$ - Sulfur & 32.5 \\
$\mathrm{Mn}$ - Manganese & 0.636714 \\
$\mathrm{Zn}$ - Zinc & 0.199144 \\
$\mathrm{Cu}$ - Copper & 0.0671 \\
$\mathrm{Bo}$ - Boron & 0.356592 \\
$\mathrm{Mo}$ - Molybdenum & 0.114452 \\
$\mathrm{Fe}-$ Iron & 2.234 \\
\hline
\end{tabular}

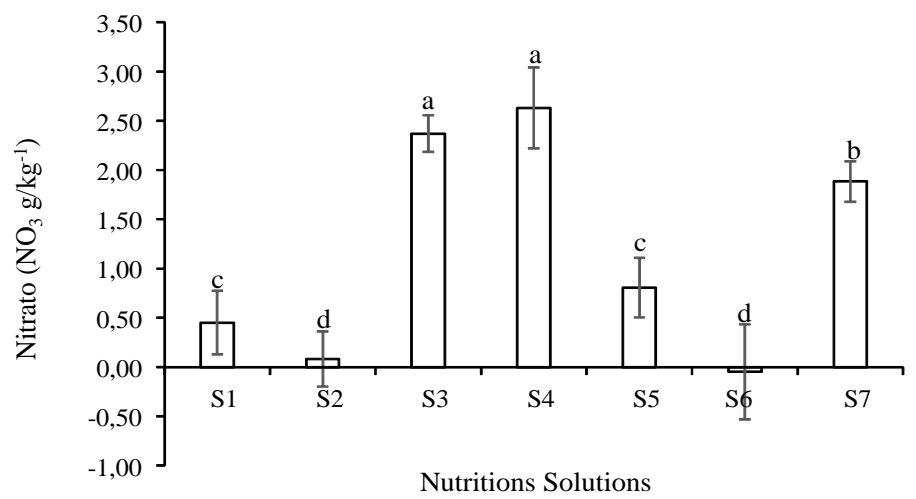

Fig 4. Determination of the nitrate content $\left(\mathrm{NO}_{3}-\mathrm{g} \mathrm{kg}^{-1}\right)$ as a function of the isolated effect of the solutions of the cultivars of the crisp lettuce Thaís, Vanda and Verônica at the end of the second experiment. Means followed by the same lowercase letters do not differ in the same cultivar. $\mathrm{S}_{1}=$ Furlani solution, $\mathrm{S}_{2}=$ domestic wastewater, $\mathrm{S}_{3}=$ optimized domestic wastewater, $\mathrm{S}_{4}=$ well water $\mathrm{S}_{5}=$ optimized well water; $\mathrm{S}_{6}=$ reactor waste-water solution and $\mathrm{S}_{7}=$ optimized reactor waste water solution.

Table 5. Quantitative of the fertilizers used in the preparation of mineral nutrient solutions from the physico-chemical characterization of the waters used in hydroponic irrigation.

\begin{tabular}{llll}
\hline \multirow{2}{*}{ Ingredients } & \multicolumn{3}{l}{ Quantity of ingredients used to prepare optimized solutions } \\
\cline { 2 - 4 } & $\mathrm{S}_{3}$ & $\mathrm{~S}_{5}$ & $\mathrm{~S}_{7}$ \\
\hline Wastewater from the (UASB) reactor & $199.58 \mathrm{~L}$ & - & - \\
Well water & - & $199.64 \mathrm{~L}$ & - \\
Raw sewage & - & - & $199.64 \mathrm{~L}$ \\
{$\left[\left(\mathrm{NH}_{4}\right)_{2} \mathrm{SO}_{4}\right]$} & $23.66 \mathrm{~g}$ & $22.31 \mathrm{~g}$ & $25.09 \mathrm{~g}$ \\
{$\left[\left(\mathrm{NO}_{3}\right)_{2}\right]$} & $238.24 \mathrm{~g}$ & $237.53 \mathrm{~g}$ & $193.54 \mathrm{~g}$ \\
$\left(\mathrm{KNO}_{3}\right)$ & $84.06 \mathrm{~g}$ & $80.95 \mathrm{~g}$ & $121.74 \mathrm{~g}$ \\
$(\mathrm{KCl})$ & $46.32 \mathrm{~g}$ & $50.04 \mathrm{~g}$ & $0.00 \mathrm{~g}$ \\
$\left(\mathrm{CuSO}_{4}\right)$ & $0.04 \mathrm{~g}$ & $0.04 \mathrm{~g}$ & $0.04 \mathrm{~g}$ \\
$\left(\mathrm{ZnSO}_{4}\right)$ & $0.11 \mathrm{~g}$ & $0.11 \mathrm{~g}$ & $0.11 \mathrm{~g}$ \\
$\left(\mathrm{MnSO}_{4}\right)$ & $0.49 \mathrm{~g}$ & $0.49 \mathrm{~g}$ & $0.49 \mathrm{~g}$ \\
$\left(\mathrm{MgSO}_{4}\right)$ & $2.19 \mathrm{~g}$ & $4.27 \mathrm{~g}$ & $0.00 \mathrm{~g}$ \\
$\left.\left(\mathrm{NH}_{4}\right)_{6} \mathrm{Mo}_{7} \mathrm{O}_{24}\right]$ & $0.06 \mathrm{~g}$ & $0.06 \mathrm{~g}$ & $0.06 \mathrm{~g}$ \\
$\left(\mathrm{H}_{3} \mathrm{BO}_{3}\right)$ & $0.42 \mathrm{~g}$ & $0.42 \mathrm{~g}$ & $0.42 \mathrm{~g}$ \\
$(\mathrm{MAP})$ & $3.14 \mathrm{~g}$ & $10.43 \mathrm{~g}$ & $5.14 \mathrm{~g}$ \\
$(\mathrm{FeSO}$ & $12.05 \mathrm{~g}$ & $12.05 \mathrm{~g}$ & $12.05 \mathrm{~g}$ \\
\hline
\end{tabular}

Note: Ammonium sulfate $\left[\left(\mathrm{NH}_{4}\right)_{2} \mathrm{SO}_{4}\right]$; Calcium nitrate $\left[\left(\mathrm{NO}_{3}\right)_{2}\right]$; Potassium nitrate $\left(\mathrm{KNO}_{3}\right)$; Potassium chloride $(\mathrm{KCl}) ;$ Copper Sulfate $\left(\mathrm{CuSO}_{4}\right) ; \mathrm{Zinc}$ sulfate $\left(\mathrm{ZnSO}_{4}\right) ;$ Manganese Sulfate $\left(\mathrm{MnSO}_{4}\right) ;$ Magnesium sulphate $\left(\mathrm{MgSO}_{4}\right) ;$ Ammonium molybdate $\left[\left(\mathrm{NH}_{4}\right)_{6} \mathrm{Mo}_{7} \mathrm{O}_{24}\right]$; Boric acid $\left(\mathrm{H}_{3} \mathrm{BO}_{3}\right)$; Monoammonium phosphate (MAP); Iron sulphate $\left(\mathrm{FeSO}_{4}\right) ; \mathrm{S}_{3}=$ optimized domestic wastewater; $\mathrm{S}_{5}=$ optimized well water and $\mathrm{S}_{7}=$ optimized reactor waste water solution. 


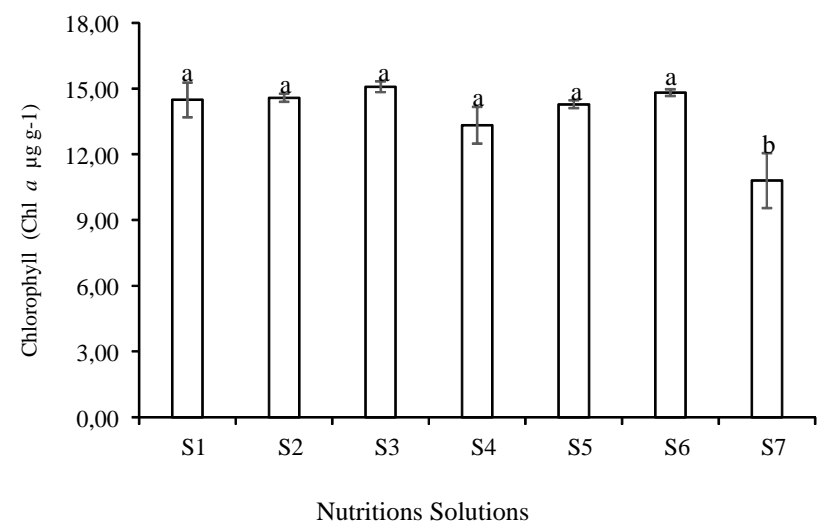

Fig 5. Determination of chlorophyll a $\left(\mathrm{Chl} \mathrm{a} \mu \mathrm{g} \mathrm{g}^{-1}\right)$ as a function of the isolated effect of nutrient solutions $\mathrm{S}_{1} ; \mathrm{S}_{2} ; \mathrm{S}_{3} ; \mathrm{S}_{4} ; \mathrm{S}_{5} ; \mathrm{S}_{6}$ and $\mathrm{S}_{7}$ at the end of the third experiment. Means followed by the same letter, the solutions do not differ. $\mathrm{S}_{1}=$ Furlani solution; $\mathrm{S}_{2}=$ domestic wastewater; $S_{3}=$ optimized domestic wastewater, $S_{4}=$ well water $S_{5}=$ optimized well water; $S_{6}=$ reactor waste water solution and $\mathrm{S}_{7}=$ optimized reactor waste water solution.

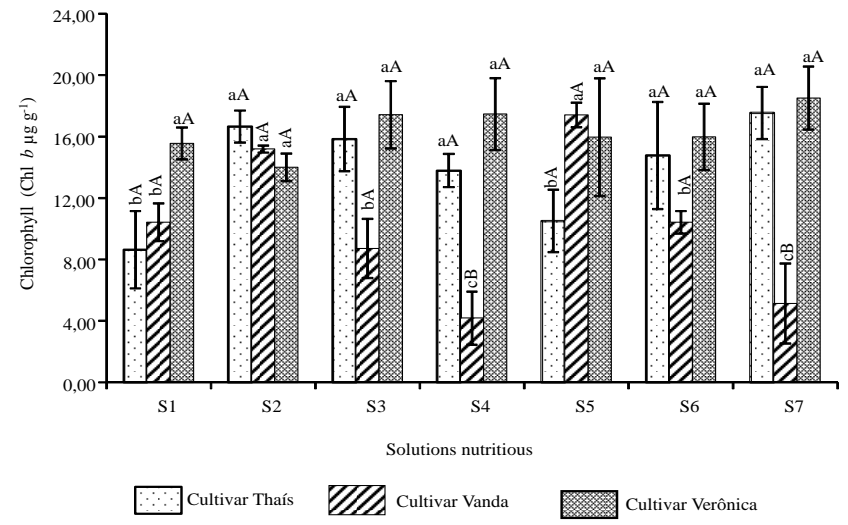

Fig 6. Determination of chlorophyll contents ( $\mathrm{Chl} \mathrm{b} \mu \mathrm{g} \mathrm{g}-1$ ) as a function of the unfolding of cultivars of crisp lettuce Thaís, Vanda and Verônica and solutions at the end of the third experiment. Means followed by the same lowercase letter, the solutions do not differ among themselves within the same cultivar and averages followed by the same capital letter. $S_{1}=$ Furlani solution; $S_{2}=$ domestic wastewater; $S_{3}=$ optimized domestic wastewater, $S_{4}=$ well water $S_{5}=$ optimized well water; $S_{6}=$ reactor waste water solution and $\mathrm{S}_{7}=$ optimized reactor waste water solution.

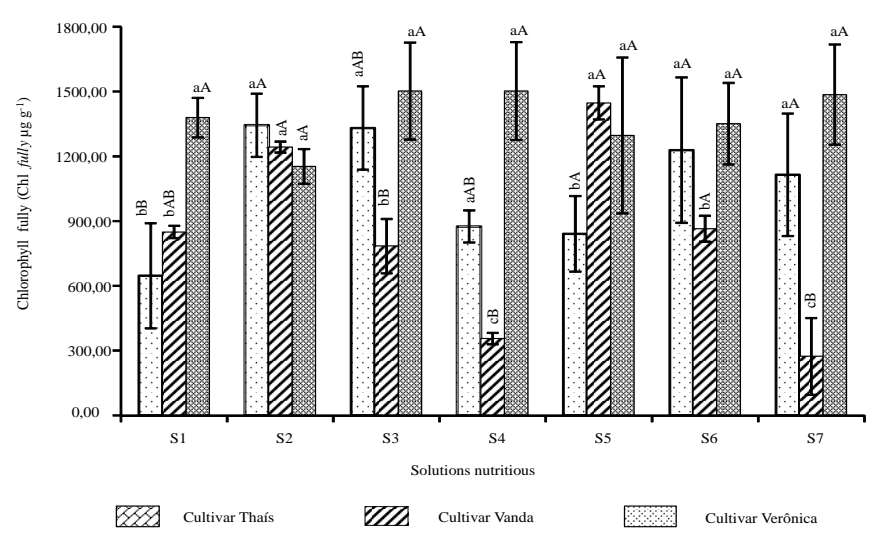

Fig 7. Determination of chlorophyll content (Chl total $\mu \mathrm{g} \mathrm{g}^{-1}$ ) as a function of the unfolding of cultivars of crisp lettuce Thaís, Vanda and Verônica and solutions at the end of the experiment. Means followed by the same lowercase letter, the solutions do not differ among themselves within the same cultivar and averages followed by the same capital letter, the cultivars do not differ among themselves within the same letter. $\mathrm{S}_{1}=$ Furlani solution; $\mathrm{S}_{2}=$ domestic wastewater; $\mathrm{S}_{3}=$ optimized domestic wastewater, $\mathrm{S}_{4}=$ well water $S_{5}=$ optimized well water; $S_{6}=$ reactor waste water solution and $S_{7}=$ optimized reactor waste water solution. 


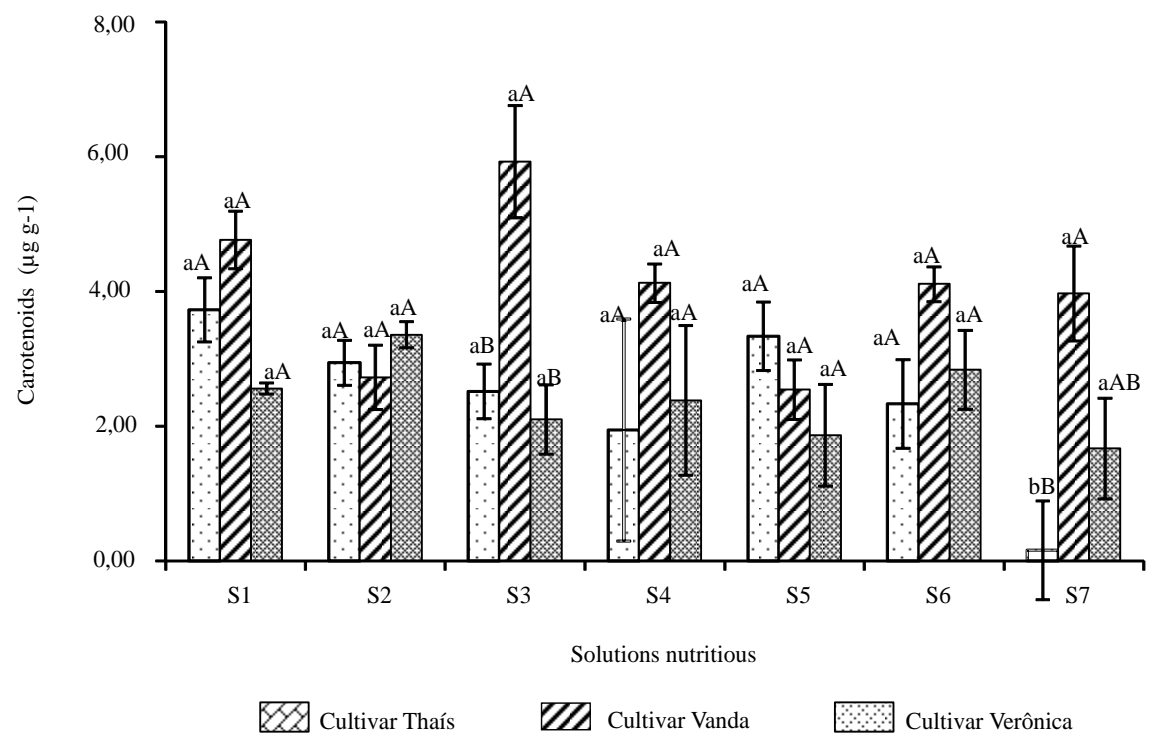

Fig 8. Determination of carotenoid contents $\left(\mu \mathrm{g} \mathrm{g}^{-1}\right)$ as a function of the unfolding of cultivars of crisp lettuce Thaís, Vanda and Verônica and solutions at the end of the third experiment. Means followed by the same lowercase letter, the solutions do not differ among themselves within the same cultivar and averages followed by the same capital letter, the cultivars do not differ among themselves within the same solution. $S_{1}=$ Furlani solution; $S_{2}=$ domestic wastewater; $S_{3}=$ optimized domestic wastewater, $S_{4}=$ well water $S_{5}=$ optimized well water; $S_{6}=$ reactor waste water solution and $S_{7}=$ optimized reactor waste water solution.

The European community established a maximum permitted limit for lettuce grown in greenhouse, $\mathrm{NO}_{3}$ - levels in the fresh mass of $3500 \mathrm{mg} . \mathrm{kg}^{-1}$ fresh mass (FM) for the verse period, $4500 \mathrm{mg} \cdot \mathrm{kg}^{-1}$ of (FM) for the winter period and $2500 \mathrm{mg} \cdot \mathrm{kg}^{-1}$ of FM the maximum allowable limit for open field lettuce McCall and Willumsen, (1998).

Analyzing the isolated effect of the cultivars, it is observed in Fig. 3 that the cultivars Thaís and Verônica presented the highest levels of nitrate and the latter did not differ statically from the Vanda cultivar.

Castro et al. (2009) compared the nitrate levels of lettuce leaves and reported higer nitrate levels compared to this study, possibly due to nitrate concentration in the vegetal tissues occurred through using sewage sludge.

As for the isolated effect of the solutions (Fig. 4), the highest nitrate levels $\left(\mathrm{NO}_{3}-\mathrm{g} \mathrm{kg-}_{-}{ }^{1}\right)$ were found in solutions $\mathrm{S}_{3}$ (optimized sewage) and $\mathrm{S}_{4}$ (well water) whose mean 2.37 and $2.63 \mathrm{~g} \mathrm{~kg}^{-1}$ and the lowest nitrate levels were $S_{2}$ and $S_{6}$, where averages 0.08 and $0.04 \mathrm{~g} \mathrm{~kg}^{-1}$ observed. The nitrate concentration in lettuce plant tissues might be different in other planting systems. For example, the nitrate levels in lettuce plants produced in the system produced in the organic system are significantly lower than in the conventional system. In turn the hydroponic systenms has shown less nitrate concentration compared to conventional method (Cavarianni et al., 2008). Matallana González et al. (2010) reported that vegetables use nitrate only for protein synthesis; however, conversion of nitrate into nitrite can occur in some cases, such as incorrect temperature and moisture condition storage that are favourable to certain activityreducing bacteria.

The main physiological factors responsible for the accumulation of nitrate in vegetables are the ability to reduce $\mathrm{NO}_{3}$ - and light consumption. Thus, the state of stress caused by temperature, lightness, and dryness reduces the $\mathrm{NO}_{3}$ reduction capacity. The increase in the availability of $\mathrm{NO}_{3}$ occurs from the organic system to the hydroponic (Sarmento et al., 2014). Jo et al. (2010) analysed nitrate contents of 550 samples, including leek and onion. They found nitrate contents of leaf vegetables were higher than those of root vegetables. The nitrate contents in leek and onions were 256.3-1491.4 $\mathrm{mg} \mathrm{kg}^{-1}, 85-323.3 \mathrm{mg} \mathrm{kg}^{-1}$, respectively.

\section{Chlorophyll content (Chl a), (Chl b) and (Chl total) and Carotenoids}

Chlorophyll content ( $\mathrm{Chl}$ a), ( $\mathrm{Chl} \mathrm{b)} \mathrm{and} \mathrm{(} \mathrm{Chl}$ total) and Carotenoids analyzed at the end of the hydroponic cultivation of the three lettuce cultivars (Vanda, Verônica, and Thaís) subjected to the different treatments (Table 2). Analysis of statistical data in Table 2 shows that for the solution factor (S) there was a significant effect at the $1 \%$ probability level ( $p$ $<0.01)$ for the variable $(\mathrm{Chl} \mathrm{a})$.

According to Mccall and Willumsen (1998) the Chl a is the most abundant and most important tan other chlorophylls in lettuce, because it corresponds to approximately $75 \%$ of the green pigments found in vegetables. A ( $\mathrm{Chl} \mathrm{b),} \mathrm{(Chl} \mathrm{total)} \mathrm{and}$ Carotenoids had no significant effect on the solution factor (S) (Table 2).

In the results of the unfolding of the nutrient solution inside cultivars and vice versa, we verified that the variable chlorophyll ( $\mathrm{Chl} \mathrm{b}$ ) and ( $\mathrm{Chl}$ total) and Carotenoids had a significant effect at $1 \%$ probability level $(p<0.01)$. For the chlorophyll variable ( $\mathrm{Chl}$ a) we verified that there was no significant effect on the unfolding (Table 2).

Fig. 5 shows that the contents of chlorophyll ( $\mathrm{Chl}$ a) as a function of the isolated effect of the nutrient solutions, $S_{1}, S_{2}$, $S_{3}, S_{4}, S_{5}, S_{6}$ do not differ. However, there is a significant difference for the $S_{7}$ solution. Analyzing Fig. 6 , it can be observed that the highest levels of chlorophyll ( $\mathrm{Chl} b$ ) were used to cultivate Thais when using the $S_{7}, S_{2}, S_{3}, S_{6}$ and $S_{4}$ solutions, whose mean values were (17.54), (16.66), (15.85),

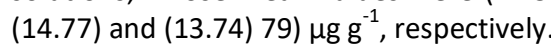


For the Vanda cultivar, the highest levels of chlorophyll (Chl b) were found in solutions $\mathrm{S} 5$ and $\mathrm{S} 2,(17.41)$ and (15.19) $\mu \mathrm{g} \mathrm{g}$ 1 , respectively. In Fig. 6, we observed that there was no difference between solutions for Veronica cultivation.

Vincent Martineau et al. (12.3 mg/100 g), chlorophyll a/b values are lower than those obtained with chlorophyll a (b) found in this. Comparing the levels of chlorophyll (Chl b) between cultivars within the same solution, we observed that there was no statistical difference using solutions $\mathrm{S}_{1}, \mathrm{~S}_{2}, \mathrm{~S}_{5}, \mathrm{~S}_{6}$ (Fig. 6). We verified in Fig. 7 that the levels of chlorophyll (total Chl) for cultivar Verônica did not present statistical difference independent of the solutions. It is also noted in Fig. 7 that the highest levels of chlorophyll (total Chl) in Vanda were found when $\mathrm{S}_{2}$ and $\mathrm{S}_{4}$ solutions were used presenting averages of $1.242 .95,1.447 .69 \mu \mathrm{g} \mathrm{g}^{-1}$, respectively. For the cultivar Thaís, the highest levels were observed in solutions $\mathrm{S}_{2}, \mathrm{~S}_{3}, \mathrm{~S}_{6}$ and $\mathrm{S}_{7}$ whose averages were 1.343.91, 1.330.92, 1.228 .63 and $1.114 .88 \mu \mathrm{g} \mathrm{g}^{-1}$, respectively. In relation to Fig. 7 , we observed that the cultivars Thaís, Vanda and Veronica presented statically the same total chlorophyll content when the solutions $S_{2}, S_{5}$, and $S_{6}$ were used. He et al. (2014) in their research found higher total $\mathrm{Chl}$ content in $200 \mathrm{HR}$ plants than in $168 \mathrm{HS}$ plants. For example, the total $\mathrm{Cl}$ content of Lattuce plants (200 HR and $168 \mathrm{HS}$ ) were, respectively, about 2000 $2060 \mu \mathrm{g} \mathrm{g}^{-1} \mathrm{FW}$ and $1700-1870 \mu \mathrm{g} \mathrm{g}^{-1} \mathrm{FW}$. Chen et al. (2014) found in their work that total $\mathrm{Chl}$ a and $\mathrm{Chl}$ content was significantly higher with FLR than other treatments. The FLR treated plants had the highest total $\mathrm{Cl}$ content of $1.31 \mathrm{mg} \mathrm{g}^{-1}$ and the lowest $\mathrm{Chl} \mathrm{a,} \mathrm{Chl} \mathrm{b} \mathrm{e} \mathrm{Car} \mathrm{were} \mathrm{all} \mathrm{detected} \mathrm{under}$ monocromic R. Ferruzzi and Blakeslee (2007) reported that chlorophylls are also important plant pigments in green leafy vegetables and are increasingly linked to some of the positive effects associated with vegetable consumption, particularly their potential cancer preventive activity. Analysis of the carotenoid contents in Fig. 5, verified that there was no statistically independent difference of the solution used for the cultivars, Vanda and Veronica. In order to cultivate Thaís, the same behavior was observed with the exception of the $S_{7}$ solution. As for the effect of cultivation within the same solution, we verified that the Vanda cultivar presented higher levels of carotenoid when the solutions $S_{3}$ and $S_{7}$ were used. However, in the latter solution, there was also no significant difference between the Vanda and Veronica cultivars (Fig. 5). Cruz et al. (2012) reported that the concentrations of carotenoids in lettuce were significantly affected by the presence of SCG in the culture medium. Regardless of the carotenoid analyzed, there is a marked improvement with the increase of SCG in the culture medium, for all values tested.

\section{Materials and methods}

\section{Plant materials}

The cultivars (Thaís, Vanda e Verônica) were selected for the research becuase of their popularity in hydroponic Nutrient Film Technique (NFT) system. They are adaptive to the climate conditions verified on site. We identified few informations on the physiological conditions of the cultivars using pure and optimized wastewater, highlighting the good cosumer acceptance on local stores.

\section{Experimental area location}

The experiment was conducted in a hydroponic system using the Nutrient Film Technique (NFT) technique in a protected environment of the State University of Paraíba, Campus II, in the municipality of Lagoa Seca-PB in the year 2016. The following geographical coordinates: $7^{\circ} 10$ '15 "S, 35 ${ }^{\circ} 51^{\prime} 14^{\prime \prime}$ $\mathrm{W}$, according to the Köppen-Geige climatic classification (Brazil, 1971).

\section{Experimental installation and conduction}

The experimental design was a randomized block with the treatments in subdivided plots (Split-plots), with three replications whose factors were seven hydroponic solutions, with the conductivity of $1.7 \mathrm{dS} . \mathrm{m}^{-1}$ and three lettuce cultivars. The main experimental units consisted of nutrient solutions (S).

The sub-plots were the hydroponic solutions with conductivity of $1.7 \mathrm{dS} \mathrm{m}^{-1} ; \mathrm{S}_{1}=$ Furlani solution; $\mathrm{S}_{2}=$ domestic wastewater; $S_{3}=$ optimized domestic wastewater; $S_{4}=$ well water; $S_{5}=$ optimized well water; $S_{6}=$ wastewater solution from the Upflow Anaerobic Sludge Blanket (UASB) reactor and $S_{7}=$ optimized wastewater solution from the UASB reactor and the subplot for three lettuce cultivars; Verônica, Vanda e, and Thais. Each subplot was composed of six plants (two plants of each cultivar) with the spacing of $0.30 \mathrm{~m} \times 0.30$ m.

The water used in the experiment originated from rainwater stored in a cistern for the (solution $S_{1}$ ), from the raw sewage of the city of Lagoa Seca-Paraíba (solutions $S_{2}$ and $S_{3}$ ). Brackish water from a tubular well in the rural area of Lagoa Seca- PB (solutions $\mathrm{S}_{4}$ and $\mathrm{S}_{5}$ ), and wastewater from the UASB reactor of the Experimental Station of Biological Treatment of Sanitary Sewers (EXTRABES) Campina Grande-Paraíba (solutions $\mathrm{S}_{6}$ and $\mathrm{S}_{7}$ ) were obtained and sent to the physicochemical analysis in the Laboratory of Irrigation and Salinity of the Academic Unit of Agricultural Engineering of the Federal University of Campina Grande (LIS/UAEA/UFCG). Table 3 shows the results of the physical-chemical characterization of the water used in hydroponic irrigation, using APHA (1998).

The nutrient solutions $S_{3}, S_{5}$, and $S_{7}$ were prepared according to the methodology proposed by Furlani (1995). The chemical composition of mineral nutrient solutions is shown in Table 4. Once formulated, the organic ingredients were mixed with mineral fertilizers when necessary, so as to present chemical composition similar to that of the Furlani solution (Table 5). During the experiment, the $S_{1}$ and optimized solutions were calibrated by means of electric conductivity (EC) and potential of hydrogen $(\mathrm{pH})$ reading, using a portable conductivity meter, in addition to a peagram. The EC was maintained at approximately $1.7 \pm 0.3 \mathrm{dS} \mathrm{cm}^{-1}$ and the $\mathrm{pH}$ was between 6.0 and 7.0. Independently ferom the treatments, the nutritive solutions were exchanged in equidistant periods of 7 days.

\section{Evaluated characteristics}

To determine the nitrate content, the analysis method proposed by Cataldo et al. (1975) was used based on the complex of salicylic acid with nitrate ion, with some modifications. Drying the samples were done in an oven at 50 
oC for 48 hours or until obtaining the constant weight. The dried material was ground in a Willey mill. As for the reading, this was done in absorbance in the spectrophotometer, at the wavelength of $410 \mathrm{~nm}$.

To determine the vitamin C content, $15 \mathrm{~g}$ of leaf was weighed and the following solutions were used: I - 1\% oxalic acid solution ( $1 \mathrm{~g}$ of oxalic acid PA was weighed and diluted in deionized water to $100 \mathrm{ml}$ ); II - Standard ascorbic acid solution $1 \mathrm{mg} \cdot \mathrm{ml}^{-1}, 0.05 \mathrm{~g}$ of standard ascorbic acid, stored shelled from light and accurately weighed at the time of use; III - 2,6-dichlorophenol indophenol standard solution (0.05 g of dichlorophenol, weighed in a desiccator and dissolved in $50 \mathrm{ml}$ of deionized water in a $200 \mathrm{ml}$ volumetric flask). The calculation and the expression of the results were performed according to Brazil (1986).

The determination of chlorophyll content was carried out using the method described by (Lichtenthaler, 1987) and the results were quantified with a UV-1000A Digital Spectrophotometer at the wavelengths of $663 \mathrm{~nm}$ (OD 663) for chlorophyll a (Chl a), $645 \mathrm{~nm}$ (OD 645) for chlorophyll b (Chl b), and $470 \mathrm{~nm}$ (OD 470) for carotenoid (Car).

\section{Statistical analysis}

Both analyzes were carried out at the Laboratory of Irrigation and Salinity, Academic Unit of Agricultural Engineering, Federal University of Campina Grande (LIS/UAEA/UFCG). The obtained data were submitted to analysis of the variance by the test $F$ to 1 and $5 \%$ of probability. When a significant effect was verified in the analysis of variance, the averages obtained in the different treatments were compared by the Tukey test up to $5 \%$ probability using the statistical software SISVARstatistical analysis system (Ferreira, 2014).

\section{Conclusions}

The cultivar Thaís presented lower Content of vitamin C (VCC) with the solution $S_{1}$. The highest content of vitamin $C$ was found in the Vanda cultivar using the $S_{1}$ solution and for the Veronica cultivar. The highest levels of vitamin $C$ were observed in solutions $\mathrm{S}_{1}, \mathrm{~S}_{2}, \mathrm{~S}_{3}, \mathrm{~S}_{4}$, and $\mathrm{S}_{7}$. In relation to the three cultivars, application of $S_{2}$ and $S_{3}$ solutions did not differ from each other. For the Vanda cultivar, solutions $S_{1}, S_{4}$ and $\mathrm{S}_{7}$ were the ones that promoted the highest levels of nitrate of, $4.61,3.32$ and $2.64 \mathrm{~g} \mathrm{~kg}^{-1}$, respectively. Evaluating the effect of the solution within the cultivars, we verified that the highest nitrate values obtained using $S_{2}$ solution for cultivars Thais and Verônica. Regarding the $S_{5}$ solution, the Verônica cultivar presented the highest concentration of this nutrient. In order to cultivate Thaís, the highest contents of chlorophyll b were found in solutions $S_{7}, S_{6}, S_{4}, S_{3}$ and $S_{2}$, where they did not differ significantly. Regarding to Vanda cultivar the highest values of chlorophyll b were present in solutions $S_{2}$ and $S_{5}$. The Verônica cultivar independent of the solution presented the same values of this pigment.

\section{Acknowledgments}

We are thankful to the National Council of Scientific and Technological Development - CNPq for the granting of a financial support grant to carry out the research.

\section{References}

Alencar TA, Tavares AT, Chaves PPN, Ferreira TA, Nascimento IR (2012) Efeito de intervalos de aplicação de urina bovina na produção de alface em cultivo protegido. Rev. Verde. 7: 53-67.

APHA, (1998) Standard Methods for the Examination of Water and Wastewater, 18th ed. American Public Health Association, Washington, DC, USA.

Brasil (1971) Ministério da Agricultura. Equipe de Pedologia e Fertilidade do Solo. Levantamento exploratório. Reconhecimento de solos do estado da Paraíba. Rio de Janeiro, SUDENE, 670p. (Boletim Técnico, 15).

Brasil (1986) Leis, decretos, etc. Portaria n 076 de 27 de novembro de 1986. Diario Oficial da União, seção 1 , p.18168.

Castro E, Mañas MP, Las Heras J (2009) Nitrate content of lettuce (Lactuca sativa L.) after fertilization with sewage sludge and irrigation with treated wastewater, Food Addit Contam Part A. 6: 172-179.

Cavarianni RL, Cecílio Filho AB, Cazetta JO, May A (2008) Concentrações de nitrogênio na solução nutritiva e horários de colheita no teor de nitrato em rúcula. Rev Caatinga. 21: 44-49.

Cataldo DA, Haroon LV, Schrader LE, Youngs VL (1975) Rapid colorimetric determination of nitrate in plant tissue by nitration of salicilic acid. Commun Soil Sci Plant Anal. 6:7 18.

Couto MAL, Canniatti-Brazaca SG (2010) Quantificação de vitamina $\mathrm{C}$ e capacidade antioxidante de variedades cítricas. Ciênc Tecnol Aliment. 30: 15-19.

Cova AMW, Freitas FTO, Viana PC, Rafael MRS, Azevedo Neto $A D$, Soares TM (2017) Content of inorganic solutes in lettuce grown with brackish water in different hydroponic systems. Rev Bras Eng Agríc Ambient. 21: 150-155.

Cru R, Baptista P, Cunha S, Pereira JA, Casal S (2012) Carotenoids of Lettuce (Lactuca sativa L.) Grown on Soil Enriched with Spent Coffee Grounds. Molecules. 17: 15351547.

Faquin V, Andrade AT (2004) Nutrição mineral e diagnose do estado nutricional de hortaliças. UFLA/FAEPE.

Ferreira DF (2014) Sisvar: A Guide for its Bootstrap procedures in multiple comparisons. Ciênc Agrotec. 38:109112.

Ferruzzi MG, Blakeslee J (2007) Digestion, absorption, and cancer preventative activity of dietary chlorophyll derivatives. Nutr Res. Doi:10.1016/j.nutres.2006.12.003.

Furlani PR, Silveira LCP, Bolonhezi D, Faquim V (1999) Cultivo hidropônico de plantas. Campinas: IAC. 52p. (Boletim técnico, 180).

He J, Seet LT L, Choong TW, Qin L, Dodd IC (2014) Effects of $\mathrm{NO}_{3}-$ Availability on Total Productivity, Root Morphology, Photosynthesis and Nitrogen Metabolism of Lettuce (Lactuca sativa L.) Recombinant Inbred Lines. Plant Sci J. 8, 24-30.

Jo SA, Kim EH, Han SH, Yuk DH, Kim JH, Park SG (2010) Analysis of nitrate contents of agricultural products by HPLC-UV. J Korean Soc Food Sci Nutr. 39(9): 1335-1339

Lichtenthaler HK (1987) Chlorophylls and carotenoids: pigments of photosynthetic biomembranes. In: Packer, L.; Douce, R. (Eds.). Methods in enzimology. London: Academic Press. 
Maynard DN, Barker AV, Minotti PL, Peck NH (1976) Nitrate accumulation in vegetables. Adv Agron. 28: 71- 118.

Matallana González MC, Martínez-Tomé MJ, Torija Isasa ME (2010) Nitrate and nitrite content in organically cultivated vegetables. Food Addit Contam Part B Surveill. 3 (1), 19-29.

Martineau V, Lefsrud M, Tahera N, Kopsell DA (2012) Comparison of Light-emitting Diode and High-pressure Sodium Light Treatments for Hydroponics Growth of Boston Lettuce. HortScience. 47(4): p.477- 481.

Martins C, Riella MC (1993) Composição e valor nutritivo dos alimentos. In: Riella, M. C. Suporte nutricional parenteral e enteral. 2. ed. Rio de Janeiro: Guanabara Koogan.

Mccall D, Willumsen J (1998) Effects of nitrate, ammonium and chloride application on the yield and nitrate content of soil-grown lettuce. J Hortic Sci Biotechnol. 73: 698-703.

Ohse S, Neto Durval D, Marodin VS, Manfron PA, Aita A (2001) Teores de nitrato e de vitamina C em alface produzida em Santa Maria/Rio Grande do Sul: Um Estudo Preliminar. Insula. 30: 63-73.

Oliveira FA, Carrilho MJSO, Oliveira MKT, Freitas DC (2009) Cultivares de Alface Produzida em Condições Salinas. Rev Caatinga. 22: 81-88.

Pimentel C (1998) Metabolismo de carbono na agricultura tropical. Seropédica- RJ: Edur, p.150.
Rego GM, Possamai, E (2006) Efeito do sombreamento sobre o teor de clorofila e crescimento inicial do Jequitibá-rosa. Boletim de Pesquisa Florestal, Embrapa Florestas.

Sala FC, Costa CP (2012) Retrospectiva e tendência da alfacicultura brasileira. Rev Hortic Bras. 30: 187-194.

Santos OS (2012) Cultivo hidropônico. Santa Maria: UFSM.

Silva EMNCP, Ferreira RLF, Araújo Neto SE, Tavella LB, Solino AJS (2011) Qualidade de alface crespa cultivada em sistema orgânico, convencional e hidropônico. Rev Hortic Bras. 29: 242-245.

Sarmento JDA, Morais PLD, Almeida M B, Sousa Neto ON, Dias NS (2014) Qualidade e Conservação da Alface Cultivada Com Rejeito Da Dessalinização. Rev Caatinga. 27: $90-97$.

Taiz L, Ziegler E (2006). Fisiologia vegetal. Traduzido Santarém E. R. et al.3.ed. Porto Alegre: Artmed.

Teixeira Neto F (2009) Nutrição clínica Rio de Janeiro: Guanabara Koogan.

Xiao-li Chen, Wen-zhong Guo, Xu-zhang Xue, Li-chun Wanga, Xiao-jun Qiao (2014) Growth and quality responses of 'Green Oak Leaf' lettuce as affected by monochromic or mixed radiation provided by fluorescent lamp (FL) and lightemitting diode (LED). Sci Horti. 172 168-175. 